\title{
\begin{tabular}{l|l|l} 
Jurnal Eksplorasi Akuntansi & e-ISSN : 2656-3649 (Online) \\
Vol. 3, No 3, Agustus 2021, Hal 640-652 & http://jea.ppj.unp.ac.id/index.php/jea/index
\end{tabular}
}

\section{Pengaruh Ukuran Perusahaan, Umur Perusahaan, Laba dan Arus Kas terhadap Kondisi Financial Distress Perusahaan Manufaktur Sektor Industri Barang Konsumsi}

\author{
Hanifa Ramadhany ${ }^{1 *}$, Efrizal Syofyan ${ }^{2}$ \\ ${ }^{1,2}$ Fakultas Ekonomi, Universitas Negeri Padang \\ *Korespondensi: hnfarmdhny@gmail.com
}

\begin{abstract}
This study aims to determine the effect of company size, company age, profit, and cash flow on financial distress conditions carried out by manufacturing companies in the consumer goods industry sector listed on the Indonesia Stock Exchange. The population of this study are manufacturing companies in the consumer goods industry sector listed on the Indonesia Stock Exchange in 2017 - 2019. The sample is determined using the purposive sampling method consisted of 46 companies. The results showed that firm size, profit and cash flow has a negative effect on financial distress conditions. While the age of the company has no effect on the condition of financial distress.
\end{abstract}

Keywords : cash flow; company age; company size; financial distress; profit.

How to cite (APA 6 $^{\text {th }}$ style)

Ramadhany, H. \& Syofyan, E. (2021). Pengaruh Ukuran Perusahaan, Umur Perusahaan, Laba dan Arus Kas terhadap Kondisi Financial Distress Perusahaan Manufaktur Sektor Industri Barang Konsumsi. Jurnal Eksplorasi Akuntansi, 3(3), 640-652

\section{PENDAHULUAN}

Dengan berkembangnya zaman, maka semakin banyak pula pengusaha yang bersaing untuk menarik perhatian konsumen. Berbagai inovasi dan hal-hal baru mulai bermunculan. Seperti berpacu dalam kecanggihan teknologi, makanan atau minuman kekinian, fashion yang semakin trendy, dan lain sebagainya. Namun dengan semakin tingginya angka persaingan, maka tidak sedikit pula perusahaan yang mengalami kondisi penurunan keuangan dan bahkan mengalami kebangkrutan karena tidak mampu mengantisipasi kemajuan zaman dan minat pelanggan yang semakin lama semakin bertambah.

Seperti diketahui pertumbuhan industri Fast Moving Consumer Good (FMCG) di Indonesia cenderung mengalami perlambatan dalam beberapa tahun terakhir. Pada tahun 2017, industri ini hanya mengalami pertumbuhan $2,7 \%$, dibandingkan dengan pertumbuhan $11 \%$ CAGR dari tahun 2003 hingga 2017 (CNBC Indonesia, 2018). Bahkan kinerja sektor industri barang konsumsi (Consumer goods) di Bursa Efek Indonesia juga semakin suram, sejak awal tahun kinerjanya anjlok hingga mendekati 20\%, tepatnya 19,31\% (CNBC Indonesia, 2019).

Melambatnya pertumbuhan konsumsi rumah tangga juga menjadi salah satu akibat menurunnya kinerja keuangan pada beberapa perusahaan besar, contohnya saja pada tahun 2019, Unilever Indonesia Tbk (UNVR), Mayora Indah Tbk (MYOR), dan Garudafood Putra 
Putri Jaya Tbk (GOOD). Laba bersih ketiga emiten tersebut turun masing-masing sebesar 4,37\% untuk UNVR, 0,51\% untuk MYOR, dan paling besar dialami GOOD mencapai 19,9\%. (Katadata, 2020).

Penurunan laba UNVR juga didorong penurunan penjualan dari sektor makanan dan minuman. Divisi tersebut hanya meraih penjualan $\mathrm{Rp} 3,1$ triliun, turun sekitar 8,8\% dibandingkan dengan perolehan Rp 3,4 triliun tahun lalu. (Katadata, 2020). Berbeda dengan dua emiten lainnya, MYOR dan GOOD yang juga mengalami penurunan laba tetapi disebabkan oleh faktor lain. Peningkatan beban usaha yang lebih tinggi dari pertumbuhan penjualan yang akhirnya menggerus laba kedua perusahaan ini. (Katadata, 2020).

Istilah umum untuk menggambarkan beberapa situasi dimana perusahaan menghadapi masalah kesulitan keuangan (financial distress) tersebut adalah kebangkrutan, kegagalan, ketidakmampuan melunasi hutang. Situasi ini biasanya dapat diketahui dengan adanya penundaan pengiriman, penurunan kualitas produk, atau adanya penundaan pembayaran bank. Apabila financial distress telah diketahui sejak awal, diharapkan agar dapat segera melakukan tindakan untuk memperbaiki situasi tersebut sehingga perusahaan tidak mengalami kebangkrutan atau likuidasi (Mamang Hariyanto, 2018).

Kondisi financial distress dapat diketahui dan diukur dengan menggunakan laporan tahunan dan laporan keuangan perusahaan yang bersangkutan. Ukuran perusahaan menjadi salah satu cara untuk mengetahui apakah perusahaan akan mengalami kondisi financial distress atau tidak. Ukuran suatu perusahaan merupakan sebuah gambaran kondisi keuangan perusahaan tersebut, karena ukuran perusahaan mampu menunjukkan jumlah asset yang dimiliki oleh suatu perusahaan (Falikhatun \& Supriyanto, 2008) dalam Puji Astuti dan Sugeng Pamudji (2015).

Lamanya suatu perusahaan belum tentu dapat memastikan apakah suatu perusahaan berada dalam kondisi financial distress atau tidak. Dalam Puji Astuti, Sugeng Pamudji (2015), menurut Storey (1994) dalam Dylan (1996) semakin lama suatu perusahaan menjalani dunia perbisnisan, maka semakin kecil kemungkinan perusahaan tersebut untuk mengalami kejadian financial distress. Kondisi financial distress tentu saja akan mempengaruhi tujuan utama suatu perusahaan yaitu untuk mendapatkan laba. Laporan laba rugi disusun dengan maksud untuk menggambarkan hasil operasi perusahaan dalam suatu waktu periode tertentu. Laporan laba rugi juga diartikan sebagai gambaran keberhasilan atau kegagalan operasi perusahaan dalam upaya mencapai tujuannya. (Fanny Nailufar, Sufitrayati, dan Badaruddin, 2018).

Aliran kas sangatlah diperlukan terutama untuk mengetahui sebesar mana kemampuan perusahaan dalam mengetahui kewajiban- kewajiban yang sebenarnya (Kasmir, 2008). Perusahaan yang memiliki nilai arus kas yang rendah maka dapat dikatakan kemungkinan terjadinya kondisi financial disress semakin tinggi, dikarenakan perputaran kas dalam suatu perusahaan yang bisa dikatakan lambat sehingga perusahaan berada dalam kondisi yang memprihatinkan (Puji Astuti,Sugeng Pamudji, 2015). Semakin tingginya angka persaingan antar perusahaan tentu saja tidak menutup kemungkinan untuk suatu perusahaan mengalami kondisi financial distress. Ditambah dengan tidak stabilnya perekonomian masyarakat menjadi suatu penyebab untuk menurunkan tingkat konsumsi masyarakat. Oleh karena itu peneliti ingin menguji kembali variabel ukuran perusahaan, umur perusahaan, penggunaan laba, dan arus kas dalam memengaruhi kondisi financial distress suatu perusahaan.

\section{KAJIAN TEORI, KERANGKA KONSEPTUAL, DAN HIPOTESIS \\ Teori Agensi (Agency Theory)}

Teori agensi adalah teori yang menjelaskan hubungan kontraktual antara principal dan agent (Jensen \& Meckling, 1976). Hubungan yang dimaksud yaitu keagenan sebagai suatu kontrak kerjasama yang melibatkan dua pihak yaitu principal (pemegang saham) dan agent (manajemen) untuk melakukan aktivitas perusahaan. Dalam teori agensi, informasi akuntansi 
manajemen digunakan untuk dua tujuan. Pertama, digunakan untuk pengambilan keputusan oleh prinsipal dan agen. Dan kedua, digunakan untuk mengevaluasi dan membagi hasil sesuai dengan kontrak kerja yang telah dibuat dan disetujui. Hal ini disebut dengan performance evaluatian role yang dapat memotivasi agen untuk berusaha seoptimal mungkin (Eko Raharjo, 2007).

Kondisi financial distress itu sendiri dapat dilihat dari ketidak mampuan perusahaan dalam membayar kewajiban yang telah jatuh tempo. Laju arus kas dan besarnya laba sangat berhubungan dengan kondisi financial distress. Dengan berdasarkan pada teori keagenan, perusahaan diharapkan dapat menggunakannya sebagai alat untuk memberikan kepercayaan kepada para investor bahwa mereka akan menerima keuntungan dari dana yang telah diinvestasikannya. Hal ini berkaitan dengan keyakinan para investor bahwa manajer akan memberikan keuntungan bagi mereka.

\section{Financial Distress}

Menurut Platt dan Platt (2002) mendefinisikan financial distress sebagai tahap terakhir penurunan kondisi keuangan yang terjadi sebelum perusahaan mengalami kebangkrutan atau likuidasi. Financial distress dapat terjadi apabila suatu perusahaan mengalami kesulitan dalam memenuhi kewajiban-kewajibannya, terutama kewajiban yang bersifat jangka pendek. Informasi ini dapat digunakan oleh pihak perusahaan untuk meminimalisir hal-hal yang mungkin saja menjadi penyebab financial distress itu sendiri. Umumnya terdapat 2 (dua) sudut pandang kajian mengenai financial distress (Fahmi Irham, 2012), yaitu :

a. Model kajian perspektif teoritis yang menggunakan metode dedusi dalam kajiannya. Model ini dimulai dengan meneliti perusahaan secara normatif yang berada dalam situasi pailit.

b. Model kajian perspektif empiris (empirical perspective) yang menggunakan metode induksi. Model ini dibentuk dari pendekatan empiris yang diturunkan dari rasio-rasio keuangan perusahaan yang diawali dengan pemisahan kelompok yang pailit dan non pailit tentu saja dilakukan dengan legal.

Prediktor utama financial distress atau kebangkrutan dan arah pengaruhnya dalam probabilitas kegagalan dapat distrukturkan sebagai berikut menurut Lenox 1999, Kasier 2001, Claessens 2002, Ogawa 2003, Dewaelheyns (R. Pasaribu, 2008), dalam Gobenvy, O (2014) :

a. Kerugian, semakin merugi perusahaan maka semakin tinggi pula probabilitas perusahaan untuk mengalami distress $(+)$.

b. Hutang, kebangkrutan biasanya diawali dengan terjadinya gagal bayar, hal ini dikarenakan semakin besar jumlah hutang, maka semakin tinggi probabilitas financial distress $(+)$.

c. Umur perusahaan, umur perusahaan memiliki pengaruh berbentuk $U$ terbalik dengan probabilitas keluar dari financial distress. Pada tahap awal, peluang kegagalan meningkat, tahap perantara sesuai dengan kemungkinan kegagalan yang stabil, dan seiring bertambahnya usia, kemungkinan kegagalan menurun.

d. Ukuran perusahaan juga memiliki pengaruh berbentuk $U$ terbalik dengan probabilitas bergerak ke arah non-distress.

e. Status legal, kemampuan yang terbatas mempunyai pengaruh positif terhadap probabilitas keluar dari kondisi financial distress $(+)$.

f. Corporate shareholder, keberadaan pemilik saham memiliki pengaruh yang negatif terhadap probabilitas yang bergerak ke arah financial distress (-).

g. Jumlah kreditur, perusahaan yang memiliki banyak kreditur hampir sama gerakan yang cepat ke arah financial distress, dibanding perusahaan dengan kreditur tunggal (-). 
h. Diversifikasi, perusahaan yang terdiversifikasi memiliki probabilitas yang tinggi terhadap financial distress dibandingkan dengan perusahaan yang tidak terdiversifikasi (-).

i. Sektor industri dapat menentukan akses perusahaan terhadap keuangan.

j. Pengaruh siklus bisnis, kinerja industri yang buruk, dapat meningkatkan probabilitas perusahaan terhadap kondisi financial distress.

\section{Ukuran Perusahaan}

Menurut Suwito dan Herawati (2005), Widyantari (2011) dalam Astuti, Pamudji (2015) menyatakan bahwa semakin besar ukuran suatu perusahaan maka diharapkan mampu menyelesaikan kewajiban secara tepat waktu, sehingga resiko financial distress semakin kecil. Ukuran perusahaan menjadi variabel penting dalam menjelaskan pemilihan metode akuntansi. Ukuran perusahaan juga disebut sebagai bagian dari lingkungan kerja, dan hal tersebut akan mempengaruhi pandangan atau keputusan manajemen. Selain itu, ukuran perusahaan dapat dijadikan tolak ukur dalam menganalisis terjadinya kebangkrutan pada suatu perusahaan, semakin besar aset yang dimiliki suatu perusahaan maka perusahaan tersebut dapat digolongkan sebagai perusahaan besar (Febriyan \& Prasetyo, 2019).

\section{Umur Perusahaan}

Di dalam Astuti, Pamuji (2015), dinyatakan bahwa menurut Nugroho (2012), umur perusahaan merupakan awal perusahaan melakukan aktivitas operasional hingga dapat mempertahankan going concern perusahaan tersebut atau mempertahankan eksistensi dalam dunia bisnis. Umur suatu perusahaan dihitung dari awal perusahaan beroperasi hingga dengan tahun penelitian dilakukan. Dapat disimpulkan bahwa umur suatu perusahaan menjadi salah satu faktor yang bisa memprediksi kondisi keuangan suatu perusahaan. Semakin lama perusahaan bertahan, semakin banyak pula kemungkinan perusahaan untuk mengembalikan investasi besar karena sudah berpengalaman. (Farida, 2019) dalam Ratih Dyan (2020). Lamanya suatu perusahaan beroperasional membuktikan bahwa perusahaan mampu mendapatkan kepercayaan yang besar dari para investor.

\section{Laba}

Laba merupakan indikator utama keberhasilan perusahaan, karena itu wajar apabila perusahaan sangat memerhatikan laba. Laporan laba rugi adalah wadah dimana laba rugi perusahaan dilaporkan. Variasi dalam pelaporan laba rugi menuntut pembaca laporan keuangan untuk selalu siap terhadap perbedaan klasifikasi, jenis usaha, dan perhatian terhadap kegiatan utama (Prihadi, 2009:29) dalam Fanny Nailufar, Sufitrayati dan Badaruddin (2018).

Fitria Wahyuningtyas $(2010 ; 19)$ dalam Hariyanto (2018) menyatakan bahwa laba merupakan selisih antara pendapatan dan biaya secara akrual. Dengan kata lain, laba lebih diartikan sebagai alat pengukur kembalian atas investasi daripada hanya sekedar perubahan kas. Laba atau rugi termasuk dalam beban pajak penghasilan atas laba atau rugi sebelum pajak. Komponen laporan laba rugi antara lain penjualan barang atau jasa, harga pokok penjualan, biaya-biaya operasi, penghasilan dan biaya diluar operasi, pos-pos luar biasa dan pajak penghasilan.

\section{Arus Kas}

Reeve, dkk (2010;262-263) dalam Hariyanto (2018) menyatakan bahwa laporan arus kas menjadi salah satu laporan keuangan dasar dalam sebuah perusahaan. Laporan arus kas (statement of cash flows) berisi laporan arus kas masuk dan arus kas keluar utama dari sebuah perusahaan dalam priode tertentu. Laporan arus kas menyajikan informasi yang berguna mengenai kemampuan perusahaan untuk menghasilkan kas dari kegiatan operasi, 
mempertahankan dan meningkatkan kapasitas operasi, memenuhi kewajiban keuangan, dan membayar dividen.

Setiap perusahaan memerlukan kas dalam menjalankan aktivitas usahanya baik sebagai alat tukar dalam memperoleh barang atau jasa maupun sebagai investasi dalam perusahaan tersebut. Kas merupakan alat pertukaran dan alat pembayaran yang diterima untuk pelunasan hutang, dan dapat diterima sebagai setoran dengan jumlah sebesar nilai nominalnya, juga simpanan bank atau tempat lain yang dapat diambil sewaktu-waktu.

\section{Hipotesis Penelitian}

H1: Pengaruh ukuran perusahaan terhadap kondisi Financial Distress pada perusahaan manufaktur sektor industri barang konsumsi yang terdaftar di Bursa Efek Indonesia pada tahun 2017-2019.

H2: Pengaruh umur perusahaan terhadap kondisi Financial Distress pada perusahaan manufaktur sektor industri barang konsumsi yang terdaftar di Bursa Efek Indonesia pada tahun 2017-2019.

H3: Pengaruh laba terhadap kondisi Financial Distress pada perusahaan manufaktur sektor industri barang konsumsi yang terdaftar di Bursa Efek Indonesia pada tahun 2017-2019.

H4: Pengaruh arus kas terhadap kondisi Financial Distress pada perusahaan manufaktur sektor industri barang konsumsi yang terdaftar di Bursa Efek Indonesia pada tahun 20172019.

\section{METODE PENELITIAN}

Jenis penelitian yang digunakan dalam penelitian ini adalah penelitian asosiatif kasual dengan pendekatan kuantitatif. Menurut (Sugiyono, 2013), penelitian kuantitatif adalah penelitian yang berlandaskan pada filsafat positivisme dengan tujuan untuk menganalisis populasi atau sampel tertentu. Populasi dalam penelitian ini adalah perusahaan manufaktur sektor industri barang konsumsi yang terdaftar di Bursa Efek Indonesia tahun 2017-2019. Jumlah sampel dalam penelitian ini adalah 46 peusahaan atau sebanyak 138 sampel untuk tiga tahun pengamatan dengan menggunakan metode purposive sampling. Data perusahaan sampel ditampilkan pada tabel 1 (lampiran)'

Data yang digunakan adalah data sekunder. Data tersebut merupakan data yang didapatkan dari laporan keuangan tahunan (annual report) dan data keuangan lengkap perusahaan manufaktur sektor industri barang konsumsi yang terdaftar di BEI pada tahun 2017-2019. Diambil langsung dari situs Bursa Efek Indonesia (BEI) yaitu dari laman IDX www.idx.co.id dan situs lain yang diperlukan. Teknik pengambilan data pada penelitian ini adalah dengan menggunakan metode dokumentasi.

\section{Variabel Penelitian dan Pengukuran Variabel Variabel Dependen (Y)}

Variabel dependen dalam penelitian ini adalah financial distress. Pengukuran variabel financial distress pada penelitian ini meggunakan analisis model Zmijewski yang menggunakan analisis rasio yang mengukur kinerja, leverage, dan likuiditas suatu perusahaan untuk model prediksinya. Perusahaan dianggap distress jika probabilitasnya lebih besar dari 0 . Dengan kata lain, nilai X nya adalah 0. Maka dari itu, nilai cutoff yang berlaku dalam model ini adalah 0 . Hal ini berarti, perusahaan yang nilai $X$ nya lebih besar dari atau sama dengan 0 diprediksi akan mengalami financial distressdi masa depan (Eka Ratna \& Mochamad Rizal, 2018). 


\section{Variabel Independen $(\mathrm{X})$}

Variabel independen merupakan variabel yang mempengaruhi nilai variabel lainnya. Variabel independen yang digunakan dalam penelitian ini adalah sebagai berikut :

a. Ukuran Perusahaan

Ukuran perusahaan menggambarkan total asset yang dimiliki oleh suatu perusahaan. Ukuran perusahaan diukur dengan menggunakan jumlah total asset yang dimiliki oleh suatu perusahaan.

b. Umur Perusahaan

$$
\mathrm{SIZE}=\operatorname{Ln}(\text { Total Asset })
$$

Umur perusahaan merupakan lamanya suatu perusahaan tersebut berdiri. Umur suatu perusahaan dapat diukur dari awal mula perusahaan beroperasional.

$$
\mathrm{AGE}=\text { Tahun penelitian }- \text { Tahun tercatatnya perusahaan di BEI }
$$

c. Laba

Laba menggambarkan baiknya operasional suatu perusahaan. Pada penelitian ini, laba yang digunakan adalah laba sebelum pajak learning before tax (EBT). Dalam perhitungannya menggunakan rasio laba terhadap total asset yaitu laba sebelum pajak dibagi dengan total asset.

d. Arus Kas

$$
\mathrm{EBT}=\quad \frac{\text { Laba sebelum pajak }}{\text { Total Asset }}
$$

Arus kas adalah laporan penerimaan dan pengeluaran kas dalam periode waktu tertentu. Arus kas diukur dengan menggunakan rasio perputaran arus kas terhadap total kewajiban, yaitu arus kas operasi dibagi dengan menggunakan total kewajiban perusahaan tersebut.

$$
\mathrm{CASH}=\frac{\text { Arus Kas Operasional }}{\text { Total Kewajiban }}
$$

\section{Teknik Analisis Data}

Teknik analisis data yang digunakan dalam penelitian ini untuk mengukur hasil penelitian adalah dengan menggunakan analisis regresi linier berganda. Analisis ini digunakan untuk memprediksikan kondisi Financial Distress dengan menggunakan variabel bebas ukuran perusahaan, laba dan arus kas dengan menggunakan model berikut :

$$
\mathrm{Y}=\mathbf{a}+\mathrm{b} 1 \mathrm{SIZE}+\mathrm{b2AGE}+\mathbf{b 3 E B T}+\mathbf{b 4 C A S H}+\mathbf{e}
$$

Keterangan :

$\begin{array}{ll}\mathrm{Y} & =\text { Financial Distress } \\ \mathrm{a} & =\text { Konstanta } \\ \mathrm{b} 1, \mathrm{~b} 2, \mathrm{~b} 3, \mathrm{~b} 4 & =\text { Koefisien regresi } \\ \mathrm{SIZE} & =\text { Ukuran perusahaan } \\ \mathrm{AGE} & =\text { Umur perusahaan } \\ \mathrm{EBT} & =\text { Laba } \\ \mathrm{CASH} & =\text { Arus kas } \\ \mathrm{e} & =\text { Residual } / \text { tingkat kesalahan }\end{array}$

\section{HASIL PENELITIAN DAN PEMBAHASAN}

\section{Uji Analisis Regresi Linier Berganda}

Analisis regresi digunakan untuk mengetahui besarnya pengaruh beberapa variabel independen dengan variabel dependen, yaitu ukuran perusahaan, umur perusahaan, laba, dan 
arus kas. Dari hasil regresi linier berganda yang dilakukan dengan menggunakan SPSS versi 22 memperoleh hasil output sebagai berikut:

Tabel 2

Hasil Analisis Regresi Linier Berganda

\begin{tabular}{|c|c|c|c|c|c|c|}
\hline \multirow[b]{2}{*}{ Model } & & \multicolumn{2}{|c|}{ Unstandardized Coefficients } & \multirow{2}{*}{\begin{tabular}{|l}
$\begin{array}{l}\text { Standardized } \\
\text { Coefficients }\end{array}$ \\
Beta \\
\end{tabular}} & \multirow[b]{2}{*}{$\mathrm{T}$} & \multirow[b]{2}{*}{ Sig. } \\
\hline & & B & Std. Error & & & \\
\hline 1 & (Constant) & 2,230 & 967 & & 2,307 &, 023 \\
\hline & Ukuran Perusahaan (X1) &,- 155 & ,033 &,- 365 & $-4,726$ &, 000 \\
\hline & Umur Perusahaan (X2) & ,022 & ,016 &, 102 & 1,389 & , 167 \\
\hline & Laba (X3) & $-7,357$ & 1,237 &,- 495 & $-5,946$ &, 000 \\
\hline & Arus Kas (X4) & $-1,146$ & ,333 &,- 274 & $-3,443$ &, 001 \\
\hline
\end{tabular}

a. Dependent Variable: Financial Distress (Y)

Sumber : data sekunder yang diolah

Model regresi linier berganda dapat berdasarkan tabel 2 di atas didapatkan model sebagai berikut :

$$
\mathrm{Y}=2,230-0,155 \mathrm{SIZE}+\text { 0,022 AGE - 7,357 EBT - 1,146 CASH + e }
$$

Dari model regresi linier berganda di atas dapat disimpulkan bahwa nilai koefisien dari ukuran perusahaan adalah sebesar $-0,155$, yang artinya apabila variabel independen lainnya tetap dan ukuran perusahaan mengalami kenaikan satu poin, maka akan menurunkan kemungkinan terjadinya kondisi financial distress.

Nilai koefisien dari umur perusahaan adalah sebesar 0,022, yang artinya apabila variabel independen lainnya tetap dan umur perusahaan mengalami kenaikan satu poin, maka akan meningkatkankan kemungkinan terjadinya kondisi financial distress. Nilai koefisien dari laba adalah sebesar -7,357, yang artinya apabila variabel independen lainnya tetap dan laba mengalami kenaikan satu poin, maka kemungkinan terjadinya financial distress akan menurun. Nilai koefisien dari arus kas adalah sebesar -1,146, yang artinya apabila variabel independen lainnya tetap dan arus kas mengalami kenaikan satu poin, maka kemungkinan terjadinya financial distress akan menurun.

\section{Uji Asumsi Klasik}

\section{Uji Normalitas}

Uji normalitas digunakan untuk memastikan atau menguji apakah distribusi data mendekati distribusi normal atau tidak. Penilaian uji normalitas yaitu apabila nilai komogolov smirov $>0,05$ maka data dikatakan terdistribusi normal. Begitu pula sebaliknya.

Tabel 3

One-Sample Kolmogorov-Smirnov Test

\section{Hasil Uji Normalitas}

\begin{tabular}{lll}
\hline & & Unstandardized Residual \\
$\mathrm{N}$ & & 6 \\
\hline Normal Parameters ${ }^{\mathrm{a}, \mathrm{b}}$ & Mean &, 0000000 \\
& Std. Deviation &, 14793238 \\
Most Extreme Differences & Absolute &, 300 \\
& Positive &, 300 \\
& Negative &,- 140
\end{tabular}


a. Test distribution is Normal.

b. Calculated from data.

c. Lilliefors Significance Correction.

Sumber : data sekunder yang diolah

Berdasarkan hasil uji normalitas menggunakan uji Kolmogorov-Smirnov pada tabel 3 menunjukkan hubungan normal. Besarnya nilai test statistic (Kolomogorov-Smirnov) untuk Unstandardized Residual adalah 0,300 dengan probabilitas signifikansi 0,099 berada diatas a $=0,05$. Hal ini berarti bahwa data penelitian ini dapat dikatakan berdistribusi normal.

\section{Uji Multikolinearitas}

Uji multikolinearitas bertujuan untuk menguji dan mengetahui apakah terdapat korelasi antar regresi dengan variabel bebas. Nilai tolerance dan VIF digunakan untuk menguji ada atau tidaknya multikolinearitas antar variabel bebas, nilai yang umum untuk cut off adalah < 0,10 atau sama dengan nilai VIF > 10 (Ghozali, 2011) dalam Puji Astuti (2015).

\section{Tabel 4}

\section{Coefficients $^{\mathbf{a}}$}

\section{Hasil Uji Multikolinearitas}

\begin{tabular}{ll} 
& Standardize \\
Unstandardized & $\mathrm{d}$ \\
Coefficients & Coefficients \\
\hline
\end{tabular}

Collinearity

Statistics

\section{$\mathrm{T}$}

ol

er

an

Model

\begin{tabular}{|c|c|c|c|}
\hline \multirow{2}{*}{\multicolumn{2}{|c|}{ (Constant) }} & B & Std. Erro1 \\
\hline & & 2,230 & ,967 \\
\hline $\begin{array}{l}\text { Ukuran } \\
\text { (X1) }\end{array}$ & Perusahaan &,- 155 & ,033 \\
\hline $\begin{array}{l}\text { Umur } \\
\text { (X2) }\end{array}$ & Perusahaan & ,022 & ,016 \\
\hline Laba (X & & $-7,357$ & 1,237 \\
\hline Arus $\mathrm{Ka}$ & X4) & $-1,146$ & 333 \\
\hline
\end{tabular}

Beta $-, 365$

, 102

$-, 495$

$-, 274$ ce VIF

T Sig.

2,307,023

$-4,726 \quad, 000$

$\begin{array}{ll}, 7 & 1,303\end{array}$

$1,389 \quad, 167$

$\begin{array}{ll}, 8 & 1,186\end{array}$

,6 1,515

$-5,946 \quad, 000$

$\begin{array}{ll}, 7 & 1,385\end{array}$

a. Dependent Variable: Financial Distress (Y)

Sumber : data sekunder yang diolah

Berdasarkan tabel 4 di atas, dapat dilihat bahwa nilai VIF dari variabel ukuran perusahaan (X1) sebesar 1,303, umur perusahaan (X2) sebesar 1,186, laba (X3) sebesar 1,515, dan arus kas (X4) sebesar 1,385. Dapat disimpulkan bahwa tidak terjadinya multikolinearitas antar variabel bebas karena nilai VIF tidak lebih dari 10 .

\section{Uji Autokorelasi}

Uji autokorelasi dirancang untuk menguji apakah terdapat korelasi antara kesalahan perancu periode $t$ dan kesalahan perancu periode $\mathrm{t}-1$ dalam model regresi linier (sebelumnya). Jika ada korelasi maka disebut problem autokorelasi. 


\section{Tabel 5}

Model Summary

\section{Hasil Uji Autokorelasi}

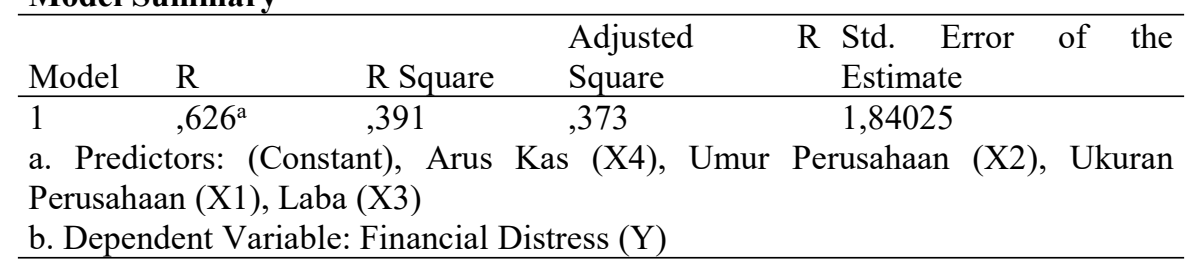

Uji autokorelasi tidak terdapatnya pelanggaran jika nilai Durbin Watson di antara -2 dan +2. Berdasarkan tabel 5 di atas didapatkan nilai Durbin Watson sebesar 1,84025. Maka dapat dikatakan bahwa tidak terdapat autokorelasi dalam model regresi yang akan digunakan karena 1,84025 berada diantar -1 dan +2 .

\section{Uji Hipotesis}

\section{Uji Simultan F}

Uji statistik F bertujuan untuk mengukur apakah semua variabel bebas (independen) yang dimaksukkan dalam model mempunyai pengaruh secara simultan terhadap variabel terikat (dependen).

\section{Tabel 6}

\section{Hasil Uji Simultan F}

\begin{tabular}{lllllll}
\multicolumn{7}{c}{ ANOVA $^{\mathbf{a}}$} \\
\hline Model & & Sum of Squares & Df & Mean Square & F & Sig. \\
\hline 1 & Regression & 289,694 & 4 & 72,423 & 21,386 &, $000^{\text {b }}$ \\
& Residual & 450,408 & 133 & 3,387 & & \\
& Total & 740,102 & 137 & & &
\end{tabular}

a. Dependent Variable: Financial Distress (Y)

b. Predictors: (Constant), Arus Kas (X4), Umur Perusahaan (X2), Ukuran Perusahaan (X1), Laba (X3)

Sumber : data sekunder yang diolah

Berdasarkan tabel 6 di atas, dengan menggunakan signifikansi 0,05 pada variabel ukuran perusahaan, umur perusahaan, laba, dan arus kas secara bersama-sama berpengaruh terhadap financial distress. Hal ini dikarenakan nilai Sig. lebih kecil dari 0,05 yaitu 0,000

\section{Uji t Test (Hipotesis)}

Uji ini bertujuan untuk menunjukan besarnya pengaruh satu variabel dengan variabel lainnya. Uji ini dapat diketahui dengan menelaah tingkat signifikansi t setiap variabel pada output hasil regresi dengan tingkat signifikan $0,05(\alpha=5 \%)$.

\section{Tabel 7}

\section{Hasil Uji t Test}

Coefficients $^{\mathrm{a}}$

\begin{tabular}{|c|c|c|c|c|c|c|}
\hline \multirow{3}{*}{$\begin{array}{l}\text { Model } \\
1\end{array}$} & & \multicolumn{2}{|c|}{ Unstandardized Coefficients } & $\begin{array}{l}\text { Standardized } \\
\text { Coefficients }\end{array}$ & \multirow[b]{2}{*}{$\mathrm{T}$} & \multirow{3}{*}{ Sig. } \\
\hline & & $\mathrm{B}$ & Std. Error & Beta & & \\
\hline & & 2,230 & 967 & & 2,307 & \\
\hline & Ukuran Perusahaan (X1) &,- 155 & 033 &,- 365 & $-4,726$ & ,000 \\
\hline & Umur Perusahaan (X2) & 022 &, 016 & 102 & 1,389 & 167 \\
\hline & Laba (X3) & $-7,357$ & 1,237 &,- 495 & $-5,946$ & 000 \\
\hline & Arus Kas (X4) & $-1,146$ &, 333 &,- 274 & $-3,443$ & 001 \\
\hline
\end{tabular}

Sumber : data sekunder yang diolah 
Berdasarkan tabel 7 di atas, diketahui nilai Sig. dari ukuran perusahaan (X1), laba (X3), dan arus kas (X4) sebesar 0,000; 0,000; dan 0,001 lebih kecil dari 0,05. Maka dapat dikatakan bahwa variabel ukuran perusahaan (X1), laba (X2), dan arus Kas (X3) memberikan pengaruh terhadap financial distress. Sedangkan nilai Sig. dari umur perusahaan (X2) sebesar 0,167 lebih besar dari 0,05. Maka dapat dikatakan bahwa variabel umur perusahaan (X2) tidak memberikan pengaruh terhadap financial distress.

\section{Uji Koefisien Determinasi $\left(\mathbf{R}^{2}\right)$}

Kecilnya determinasi nilai koefisien berarti kemampuan variabel-variabel independen dalam menjelaskan variasi dependen sangat terbatas. Sedangkan nilai $\mathrm{R}^{2}$ yang mendekati satu artinya variabel-variabel independen menyediakan semua informasi yang dibutuhkan untuk memprediksi variasi variabel dependen.

\section{Tabel 8}

Hasil Uji Koefisien Determinasi $\left(\mathbf{R}^{2}\right)$ Model Summary ${ }^{b}$

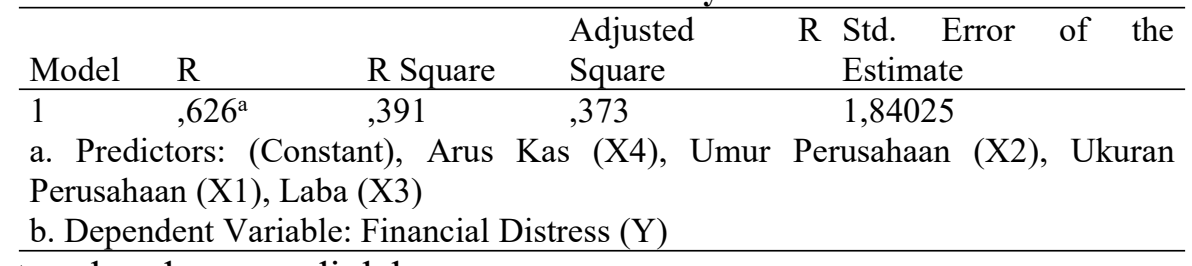

Sumber : data sekunder yang diolah

Berdasarkan tabel di atas, nilai dari $\mathrm{R}^{2}$ adalah sebesar 0,373 yang berarti $37 \%$ financial distress dapat dijelaskan oleh variabel ukuran perusahaan (X1), umur perusahaan (X2), laba (X3), dan arus kas (X4). Sedangkan sisanya sebesar 63\% ditentukan oleh variabel lain yang tidak digunakan dalam penelitian ini.

\section{Pembahasan}

Melalui analisis regresi linier berganda, dapat diketahui bahwa ukuran perusahaan memiliki pengaruh negatif dalam memprediksi kondisi financial distress. Hasil penelitian ini sesuai dengan penelitian yang dilakukan oleh Nada Mselmi, Amine Lahiani, dan Taher Hamza (2017), tetapi bertolak belakang dengan penelitian Puji Astuti dan Sugeng Pamudji (2015). Maka dapat disimpulkan bahwa ukuran perusahaan berpengaruh negatif terhadap kondisi financial distress.

Semakin besar ukuran suatu perusahaan maka semakin kecil kemungkinan perusahaan tersebut untuk mengalami kondisi financial distress. Besarnya ukuran suatu perusahaan menggambarkan jumlah total asset perusahaan tersebut. Yang mana dapat diperkirakan apakah perusahaan mampu memenuhi kewajibannya atau tidak. Hasil uji pada variabel Umur Perusahaan menjelaskan bahwa variabel ini tidak memiliki pengaruh terhadap financial distress. Hal ini menunjukkan bahwa lamanya perusahaan beroperasional tidak menentukan apakah suatu perusahaan dapat mengalami kondisi financial distress atau tidak.

Penelitian ini sejalan dengan penelitian yang dilakukan oleh Nongnit Chancharat, Pamela Davy, Michael S. McCrae, dan Gary Gang Tian (2007), tetapi bertolak belakang dengan penelitian yang dilakukan oleh Ratih Dyan Triani (2020), yang menyatakan bahwa umur perusahaan berpengaruh terhadap financial distress. Perusahaan yang sudah berdiri lama bisa saja menyelesaikan masalah dan meminimalisir hal yang menyebabkan perusahaan tersebut berada dalam financial distress. Dengan banyaknya pengalaman yang sudah dialami oleh perusahaan yang lebih lama berdiri tentu saja diharapkan dapat mempertahankan perusahaan dengan sebaik mungkin. 
Hasil pengujian tersebut juga menunjukkan bahwa laba berpengaruh negatif dalam memprediksi kondisi financial distress. Hal ini menunjukkan bahwa suatu perusahaan yang mengalami penurunan laba secara terus menerus maka semakin besar kemungkinan perusahaan tersebut untuk mengalami kondisi financial distress. Sebaliknya, bila perusahaan tersebut memiliki laba yang stabil atau laba mengalami kenaikan maka semakin kecil pula kemungkinan perusahaan tersebut mengalami kondisi financial distress.

Penelitian ini mendukung penelitian yang dilakukan oleh Kristiana Ardeati (2018) yang menyatakan bahwa laba berpengaruh terhadap financial distress. Perusahaan yang mengalami penurunan laba akan lebih besar kemungkinannya untuk mengalami kondisi financial distress. Dan sebaliknya, apabila perusahaan mengalami kenaikan laba, maka dapat dikatakan perusahaan beroperasi dengan baik dan meminimalisir kemungkinan terjadinya financial distress. Hasil pengujian tersebut juga menunjukkan bahwa arus kas berpengaruh negatif dalam memprediksi kondisi financial distress. Hal ini menunjukkan bahwa suatu perusahaan yang memiliki arus kas yang tinggi menggambarkan bahwa perusahaan beoperasional dengan baik dan semakin kecil pula kemungkinan terjadinya kondisi financial distress. Sebaliknya, bila perusahaan memiliki arus kas yang kecil atau mungkin tidak stabil maka semakin besar kemungkinan perusahaan untuk mengalami kondisi financial distress.

Penelitian ini mendukung penelitian yang dilakukan oleh Puji Astuti dan Sugeng Pamudji (2015), tetapi bertolak belakang dengan penelitian yang dilakukan oleh Naz Sayari, dan F.N. Can Simga Mugan (2013) yang menyatakan bahwa arus kas berpengaruh negatif secara signifikan terhadap kondisi financial distress. Kecilnya arus kas yang dimiliki oleh suatu perusahaan maka akan meningkatkan kemungkinan terjadinya kondisi financial distress pada perusahaan tersebut.

\section{SIMPULAN, KETERBATASAN, DAN SARAN \\ Simpulan}

Setelah dilakukan analisis data dengan menggunakan regresi linier berganda maka dapat disismpulkan sebagai berikut :

a. Ukuran Perusahaan berpengaruh negatif terhadap kondisi financial distress pada perusahaan manufaktur sektor industri barang konsumsi yang terdaftar di Bursa Efek Indonesia tahun 2017-2019.

b. Umur Perusahaan tidak berpengaruh terhadap kondisi financial distress pada perusahaan manufaktur sektor industri barang konsumsi yang terdaftar di Bursa Efek Indonesia tahun 2017-2019.

c. Laba berpengaruh negatif terhadap kondisi financial distress pada perusahaan manufaktur sektor industri barang konsumsi yang terdaftar di Bursa Efek Indonesia tahun 2017-2019.

d. Arus kas berpengaruh negatif terhadap kondisi financial distress pada perusahaan manufaktur sektor industri barang konsumsi yang terdaftar di Bursa Efek Indonesia tahun 2017-2019.

\section{Keterbatasan}

a. Tahun penelitian hanya sampai tahun 2019. Hal ini dikarenakan hingga penelitian dilakukan, data laporan keuangan perusahaan pada tahun 2020 belum dapat diakses atau dikutip.

b. Sampel penelitian hanya menggunakan sektor industri barang konsumsi saja, sedangkan terdapat banyak sektor yang dapat diteliti.

c. Penelitian ini hanya meneliti beberapa variabel, sedangkan terdapat banyak variabel lainnya yang dapat diteliti. Contoh variabel lain yang mungkin saja memiliki pengaruh terhadap kondisi financial distress adalah profitabilitas, leverage, likuiditas, rasio keuangan lainnya, good corporate governance, dan lain sebagainya. 


\section{Saran}

Saran dari peneliti untuk penelitian selanjutnya diharapkan dapat mengembangkan penelitian ini menjadi penelitian yang lebih baik. Adapun saran-saran tersebut antara lain :

a. Untuk perusahaan, hasil dari penelitian ini diharapkan dapat memberikan pemahaman lebih lanjut dalam kegiatan operasionalnya. Berkaitan dengan ukuran perusahaan, perusahaan perlu meningkatkan ukuran perusahaan atau meningkatkan total asset perusahaan dengan cara memaksimalkan seluruh asset guna untuk mendapatkan pendapatan tambahan sehingga perusahaan tidak perlu lagi melakukan hutang. Hal ini tentu saja dapat meningkatkan kinerja perusahaan dan meminimalisir terjadinya financial distress.

b. Berkaitan dengan arus kas, perusahaan diharapkan lebih mempertimbangkan kembali dalam melakukan hutang kepada kreditor. Karena nilai hutang dapat dijadikan alat pemacu dalam kinerja keuangan.

c. Berkaitan dengan laba, perusahaan diharapkan dapat memaksimalkan laba dengan melakukan penekanan pada biaya operasional. Dengan begitu, diharapkan agar lebih banyak investor yang akan mempercayakan untuk menanam investasinya ke perusahaan yang bersangkutan.

d. Penelitian selanjutnya diharapkan mempertimbangkan untuk menggunakan variabel yang lainya, selain itu juga dapat menambah periode penelitian atau pengambilan sampel penelitian yang lebih banyak lagi guna memperoleh hasil yang signifikan.

\section{DAFTAR PUSTAKA}

Altman, E., \& Hotchkiss, E. (2006). Corporate Financial Distress and Bankruptcy (Third Edition). Canada: John Wiley \& Sons, Inc.

Astuti, P., \& Pamudji, S. (2015). Analisis Pengaruh Opini Going Concern, Likuiditas, Solvabilitas, Arus Kas, Umur Perusahaan dan Ukuran Perusahaan Terhadap Kemungkinan Financial Distress. Diponegoro Journal of Accounting Vol. 4 No. 1 , 1 - 11.

Fahmi, I. (2012). Analisis Kinerja Keuangan Panduan Bagi Akademisi, Manajer, dan Investor Untuk Menilai dan Menganalisis Bisnis dari Aspek Keuangan. Bandung: ALFABETA, cv.

Febriyan, \& Prasetyo, A. H. (2019). Pengaruh Arus Kas Operasi, Likuiditas, Leverage, Diversifikasi, dan Ukuran Perusahaan Terhadap Financial Distress (Studi empiris pada perusahaan sektor aneka industri yang terdaftar di BEI 2014-2016). Jurnal Akuntansi, 8(1), Hal.103-116.

Finishtya, F. (2018). The Role Of Cash Flow Of Operational , Profitability, and Financial Leverage in Predicting Financial distress Manufacturing Company in Indonesia. Journal of Applied Management, Vol. 17 No.1 , 110 - 117.

Fitria, W. (2010). Penggunaan Laba dan Arus Kas Untuk Memprediksi Kondisi Financial Distress. Skripsi. Fakultas Ekonomi, Universitas Diponegoro. Semarang.

Gobenvy, O. (2014). Pengaruh Profitabilitas, Financial Leverage dan Ukuran Perusahaan Terhadap Financial Distress Pada Perusahaan Manufaktur Yang Terdaftar di Bursa Efek Indonesia Tahun 2009-2011. Jurnal Akuntansi Vol. 2, No. 1 .

Halim, M. (2016). Penggunaan Laba dan Arus Kas Untuk Memprediksi Kondisi Financial Distress. Jurnal Ilmiah Akuntansi Indonesia Vol. 1 No. 1 .

Haryanto, M. (2018). Pengaruh Laba dan Arus Kas Terhadap Kondisi Financial Distress. Jurnal Akuntansi dan Investasi Vol. 3 No. 1,44 - 60.

Jensen, M., \& Meckling, W. (1976). Theory Of The Firm: Managerial Behavior, Agency Costs And Ownership Structure.Journal of Financial Economics 3 , 305 - 360. 
Juniary, D. (2017). Faktor - Faktor Yang Mempengaruhi Financial Distress Pada Perusahaan Property Dan Real Estate Terbuka Di Bursa Efek Indonesia. Skripsi. Fakultas Ekonomi dan Bisnis, Universitas Sumatera Utara. Medan.

Kamaluddin, A., Ishak, N., \& Mohammed, N. (2019). Financial Distress Prediction Through Cash Flow Ratios Analysis. International Journal of Financial Research Vol. 10, No. 3 , $63-76$.

Kristiana, A. (2018). Pengaruh Arus kas, Laba, dan Leverage terhadap Financal Distress. Skripsi. Fakultas Ekonomi, Universitas Sanata Dharma. Depok.

Mselmsi, N., Lahiani, A., \& Hamza, T. (2017). Financial distress prediction: The case of French small and medium-sized firms. International Review of Financial Analysis .

Murni, M. (2018). Analisis Faktor-Faktor Yang Mempengaruhi Tingkat Financial Distress Pada Perusahaan Manufaktur Yang Terdaftar Di BEI Tahun 2010-2014. Jurnal Akuntansi dan Bisnis Vol. 4 No. 1 , 74 - 83.

Nailufar, F., Sufirayati, \& Badaruddin. (2018). Pengaruh Laba dan Arus Kas Terhadap Kondisi Financial Distress Pada Perusahaan Non Bank Yang Terdaftar Di Bursa Efek Indonesia. Jurnal Penelitian Ekonomi Akuntansi, Vol. 2 No. 2 , 147 - 162.

Platt, H., \& Platt, M. (2002). Predicting Corporate Financial Distress: Reflections on ChoiceBased Sample Bias. Journal Of Economics And Finance. Vol. 26 No. 2 , 184 - 199.

Puji, A. (2014). Analisis Pengaruh Opini Going Concern, Likuiditas, Solvabilitas, Arus Kas, Umur Perusahaan, dan Ukuran Perusahaan Terhadap Kemungkinan Financial Distress. Skripsi. Fakultas Ekonomika dan Bisnis, Universitas Diponegoro. Semarang.

Ratih, D. (2020). Pengaruh Leverage, Profitabilitas, Likuiditas, Arus kas, Ukuran perusahaan dan umur perusahaan Terhadap Financial Distress. Skripsi. Fakultas Ekonomi dan Bisnis, Universitas Pancasakti Tegal, Tegal.

Rega, D. (2020). Pengaruh Karakteristik Komite Audit dan Ukuran Perusahaan Terhadap Financial Distress. Skripsi. Fakultas Ekonomi, Universitas Negeri Padang. Padang.

Sari, E., \& Yulianto, M. (2018). Akurasi Pengukuran Financial Distress Menggunakan Metode Springate dan Zmijewski pada Perusahaan Property dan Real Estate di Bursa Efek Indonesia Periode 2013-2015. Jurnal Manajemen Bisnis Indonesia, Vol. 5, No. 2 , $276-285$. 